PNL-3479

UC-70

\title{
Description of Processes for the Immobilization of Selected Transuranic Wastes
}

\author{
C. L. Timmerman
}

December 1980

Prepared for the U.S. Department of Energy under Contract DE-AC06-76RLO 1830

Pacific Northwest Laboratory Operated for the U.S. Department of Energy by Battelle Memorial Institute 
This report was prepared as an account of work sponsored by the United States Government. Neither the United States nor the Department of Energy, nor any of their employees, nor any of their contractors, subcontractors, or their employees, makes any warranty, express or implied, or assumes any legal liability or responsibility for the accuracy, completeness or usefulness of any information, apparatus, product or process disclosed, or represents that its use would not infringe privately owned rights.

The views, opinions and conclusions contained in this report are those of the contractor and do not necessarily represent those of the United States Government or the United States Department of Energy.

\author{
PACIFIC NORTHWEST LABORATORY \\ operated by \\ BATTELLE \\ for the \\ UNITED STATES DEPARTMENT OF ENERGY \\ Under Contract DE-AC06-76RLO 1830
}

Printed in the United States of America

$$
\text { Available from }
$$

National Technical Information Service

United States Department of Commerce

5285 Port Royal Road

Springfield, Virginia 22151

Price: Printed Copy s

$\therefore$ Microfiche $\$ 3.00$

NTIS

-Pages Selling Price

$\begin{array}{ll}001-025 & \$ 4.00 \\ 026-050 & \$ 4.50 \\ 051-075 & \$ 5.25 \\ 076-100 & \$ 6.00 \\ 101-125 & \$ 6.50 \\ 126-150 & \$ 7.25 \\ 151-175 & \$ 8.00 \\ 176-200 & \$ 9.00 \\ 201-225 & \$ 9.25 \\ 226-250 & \$ 9.50 \\ 251-275 & \$ 10.75 \\ 276-300 & \$ 11.00\end{array}$


PNL -3479

UC -70

\section{3}

DESCRIPTION OF PROCESSES FOR

THE IMMOBILIZATION OF SELECTED

TRANSURANIC WASTES

C. L. Timmerman

December 1980

Prepared for the U.S. Department of Energy under Contract DE-AC06-76RLO 1830

Pacific Northwest Laboratory

Richland, Washington 99352 
Processed sludge and incinerator-ash wastes contaminated with transuranic (TRU) elements may require immobilization to prevent the release of these elements to the environment. As part of the TRU Waste Immobilization Program sponsored by the Department of Energy (DOE), the Pacific Northwest Laboratory is developing applicable waste-form and processing technology that may meet this need. This immobilization program is part of the overall TRU Waste Management Program under the direction of the lead DOE Albuquerque Operations Office and is being coordinated by the TRU Waste Systems Office of Rockwe 11 International, Rocky Flats Plant, Colorado. This report defines and describes processes that are capable of immobilizing a selected TRU waste-stream consisting of a blend of three parts process sludge and one part incinerator ash. These selected waste streams are based on the compositions and generation rates of the waste processing and incineration facility at the Rocky Flats Plant.

The specific waste forms that could be produced by the described processes include:

- in-can melted borosilicate-glass monolith

- joule-heated melter borosilicate-glass monolith or marble

- joule-heated melter aluminosilicate-glass monolith or marble

- joule-heated melter basaltic-glass monolith or marble

- joule-heated melter glass-ceramic monolith

- cast-cement monolith

- pressed-cement pellet

- cold-pressed sintered-ceramic pellet. 


\section{ACKNOWLEDGMENT}

I would like to acknowledge the assistance and input of R. L. Treat of Pacific Northwest Laboratory in developing the processes described here. I would also like to thank G. B. Long for editing and coordinating the publication of this report. 


\section{CONTENTS}

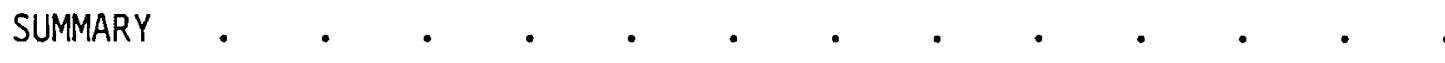

ACKNOWLEDGMENT

FIGURES

INTRODUCTION

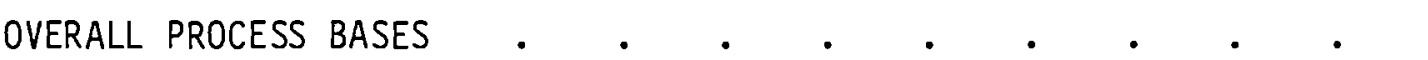

PROCESS DESCRIPTIONS AND FLOWSHEETS

IN-CAN GLASS-MELTING PROCESS

JOULE-HEATED GLASS-MELTING PROCESS

GLASS-MARBLE PROCESS $\quad$. $\quad . \quad . \quad . \quad . \quad . \quad . \quad . \quad 15$

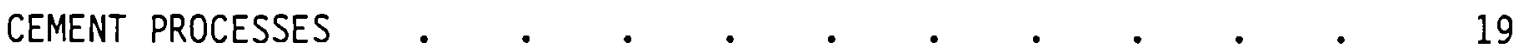

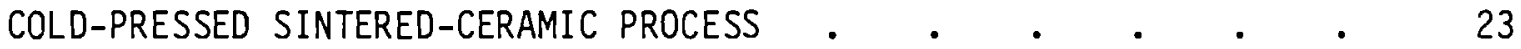

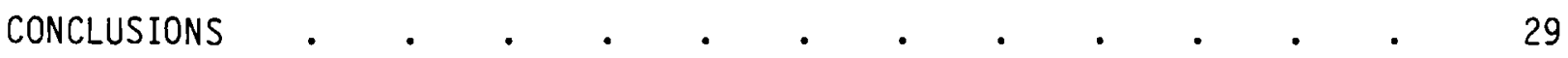

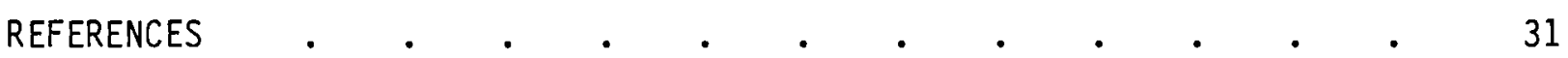




\section{FIGURES}

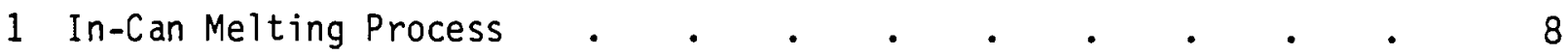

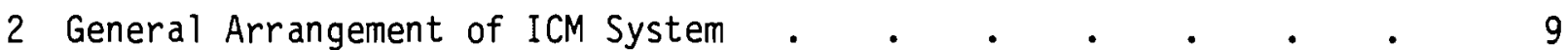

3 Schematic of the ICM Connecting Section . $\quad . \quad$. $\quad . \quad$. 10

4 Joule-Heated Glass-Melting Process . . . . . . . . . 12

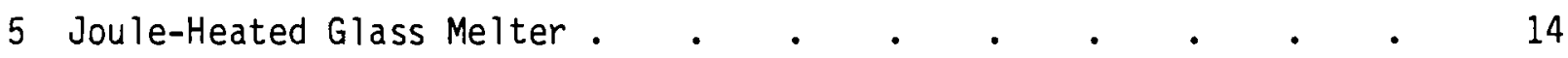

6 Glass Marble Process . . . . . . . . . . . . . . 16

7 Glass Pouring and Marble Formation . $\quad . \quad$. $\quad . \quad$. 17

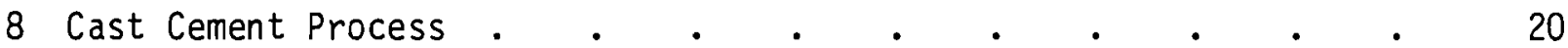

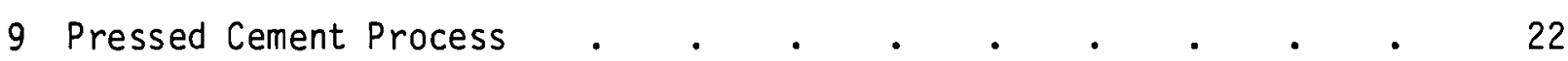

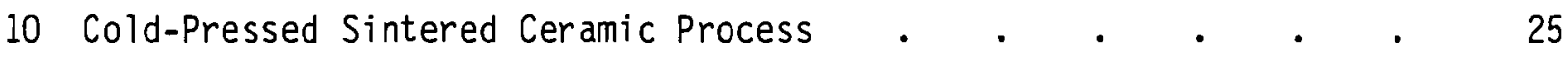




\section{INTRODUCTION}

Wastes contaminated with transuranic (TRU) elements may require treatment to prevent the uncontrolled release of these elements to the environment. A need exists to identify and characterize these wastes, to evaluate the possible immobilization requirements and treatment alternatives, and to develop immobilization process technologies to assure adequate waste confinement. The Pacific Northwest Laboratory has actively been pursuing these needs through the TRU Waste Irmobilization Project under the sponsorship of the U.S. Department of Energy. This project is intended to meet all of the above objectives.

This report concentrates on the last of the above objectives--the deve1opment of process technologies. Processes are defined and described that are capable of immobilizing a selected TRU waste-stream consisting of a blend of process sludge and incinerator ash. In this study, the process sludge is produced by the decontamination of aqueous wastes resulting from various plutonium recovery and purification processes. The aqueous wastes are decontaminated using a hydrated ferric oxide precipitate which is separated from the supernate by passage through a rotary vacuum filter. A diatomaceous earthfilter precoat enhances removal of the insoluble contaminated solids. These filtered solids and media are the process sludge. The incinerator ash comes from the burning of contaminated combustibles, such as paper, gloves, lab coats, etc. As a model for our study, we assume the ash is produced by one of two methods depending on the level of activity in the material to be incinerated. The high specific-activity ash has been incinerated in a rotary kiln incinerator and then acid-leached to recover plutonium. The low specificactivity waste has been incinerated in a stirred-bed incinerator and the ash directly discharged as waste. Both the process sludge and the incinerator ash are contaminated with small amounts of plutonium and other actinides. The presence of these contaminants may require that the wastes be immobilized prior to final disposal. This report identifies the process bases and assumptions, supplies brief process descriptions, and provides preliminary process 
flowsheets for selected immobilization schemes that can be used to process these TRU wastes. The processes described are:

- in-can glass-melting

- joule-heated glass-melting

- glass marble

- cast cement

- pressed cement

- cold-pressed sintered-ceramic. 


\section{OVERALL PROCESS BASES}

The conceptual immobilization facility is designed to solidify $285 \mathrm{MT} / \mathrm{yr}$ of TRU wastes consisting of a blend of three parts process sludge and one part incinerator ash. The assumed chemical composition of this blend is shown in Table 1. This feedrate is based up on the mass generation rates for sludge and ash at the new plutonium-recovery, volume-reduction and aqueous-waste decontamination facilities at the Rocky Flats Plant in Golden, Colorado. For a 11 but the cement processes, an average operating rate of $26.5 \mathrm{~kg} / \mathrm{h}$ of the TRU waste blend $(19.9 \mathrm{~kg} / \mathrm{h}$ of sludge and $6.6 \mathrm{~kg} / \mathrm{h}$ of ash) is assumed for a $24 \mathrm{~h} / \mathrm{d}, 300 \mathrm{~d} / \mathrm{yr}$ operation. However, all processes are designed to operate at 1.5 times the average rate or $40 \mathrm{~kg} / \mathrm{h}$ of sludge and ash at the design capacity. The cement process is the lone exception to the above flowrates, for it is based on an $8-h / d, 5-d / w k, 43-w k / y r$ operating frequency. Hence, the cement process treats an average of $110.5 \mathrm{~kg} / \mathrm{h}$ of the TRU waste blend, and the design rate is $165.8 \mathrm{~kg} / \mathrm{h}$.

The elements of each immobilization process that involve handling radioactive materials will be housed in radiation containment cells and adjoining glove boxes. Glove boxes will be used only where contact maintenance and operations are expected to be high, where remote functions are not feasible, and/or where personnel exposure is expected to be low. Some contact maintenance in the cells will likely be required although suitable design will minimize this possibility.

In order to proceed with preliminary design of the processes, the final waste package is designed to meet the following criteria:

- canister - maximum dimensions of $61 \mathrm{~cm}(2 \mathrm{ft})$ dia $\times 3.05-\mathrm{m}(10-\mathrm{ft})$ total length

- drum - $58 \mathrm{~cm}(23$ in.) dia $\times 76 \mathrm{~cm}$ (30 in.) in height

- weight - less than $11,300 \mathrm{~kg}$ total

- packaging requirements - 47 CFR 173.398 (b) Type A

- design life - $10 \mathrm{yr}$. 
TABLE 1. Assumed Chemical Compositions for Typical Sludge and Ash

Compound

$\mathrm{Al}_{2} \mathrm{O}_{3}$

$\mathrm{B}_{2} \mathrm{O}_{3}$

$\mathrm{BaO}$

$\mathrm{CaO}$

$\mathrm{C}$

$\mathrm{CO}_{2} \mathrm{O}_{3}$

$\mathrm{Cr}_{2} \mathrm{O}_{3}$

CuO

$\mathrm{Fe}_{2} \mathrm{O}_{3}$

$\mathrm{K}_{2} \mathrm{O}_{3}$

$\mathrm{MgO}$

$\mathrm{MnO}_{2}$

$\mathrm{MoO}_{3}$

$\mathrm{Na}_{2} \mathrm{O}$

$\mathrm{NiO}$

$\mathrm{P}_{2} \mathrm{O}_{5}$

$\mathrm{SiO}_{2}$

Sro

S

$\mathrm{TiO}_{2}$

$\mathrm{ZnO}_{2}$

$\mathrm{ZrO}_{2}$

$\mathrm{H}_{2} \mathrm{O}$

$\mathrm{PuO}_{2}$

Other
Composition, wt\%

\begin{tabular}{|c|c|c|}
\hline $\begin{array}{l}\text { Process } \\
\text { Sludge }\end{array}$ & $\begin{array}{l}\text { Incinerator } \\
\text { Ash(a) }\end{array}$ & $\begin{array}{c}\text { Waste } \\
\text { Blend }(b)\end{array}$ \\
\hline 1.48 & $18.50^{(c)}$ & 5.76 \\
\hline -- & .32 & .08 \\
\hline -- & . 97 & .24 \\
\hline 7.61 & 4.00 & 6.71 \\
\hline -- & 9.70 & 2.43 \\
\hline -- & .01 & -- \\
\hline -- & .10 & .03 \\
\hline -- & .02 & -- \\
\hline
\end{tabular}

21.95

.64

3.50

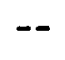

$--$

6.20

$--$

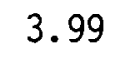

$37.58(c)$

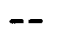

$-$

$-$

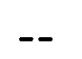

$--$

10.00

.002

$\frac{7.05}{100.002}$
1.43

.97

5.34

.02

.02

1.82

.04

4.81

25.48 (c)

.02

.36

16.82

.72

3.96

--

$-$

5.10

.01

4.19

34.55

.09

$24.26(c)$

1.67

6.07

.42

.01

7.50

.05

5.29

100.03

\footnotetext{
(a) Unleached.

(b) Based on a sludge: ash generation-rate ratio of 3 .

(c) Highly variable.
} 
The immobilization facility will receive the incinerator ash in reusable criticality-safe containers. The immobilization facility will also receive the sludge from the processing facility in slurry form from the filter feed tank and/or as dried sludge in reusable tapered drums designed to facilitate removal of the waste. Transferring the sludge as a slurry and locating the rotary vacuum filter, sludge drier and cooler in the immobilization facility is the preferred receiving method because of the ease and safety of material transfer and handling. 



\section{PROCESS DESCRIPTIONS AND FLOWSHEETS}

Various immobilization processes and a preliminary design of their flowsheets are described here. These immobilization processes form three basic waste-product forms via various processing options: glass, cement, and crystalline ceramic.

\section{IN-CAN GLASS-MELTING PROCESS}

In the In-Can Glass-Melting (ICGM) process (Blair 1979), large monoliths of a glass/waste mixture are produced. Dried sludge, ash, and borosilicate glass frit are control-fed to a continuous powder blender for homogeneous mixing. Afterwards, the blended mix flows down to a unidirectional diverter valve into a pair of In-Can Melters (ICM's). A schematic of the process flowsheet with the operating flowrates indicated is illustrated in Figure 1 . This diagram shows that only one of the two ICM's can be operating and receiving the blended mix at any given time. Figure 2 shows the general arrangement of a pair of ICM's with one canister being filled while the other is being exchanged. The Figure 3 schematic illustrates an enlarged view of the connecting section between the material flow and the canister.

The canisters heated in the ICM constitute a major component of this system. Specific design considerations of the waste canister are size, material of construction, and canister-wall thickness. The size of the canister will be determined by the maximum allowable diameter and height permitted by the repository since TRU wastes require no heat-generation constraints in repository design. Thus, the canister can be as large as the design criteria permit. From the assumptions of this study, the canister will be constructed of 304L stainless steel and will have a $61-\mathrm{cm}(2-\mathrm{ft})$ outside diameter, 58.4-cm (23-in.) inside diameter and a 3.05-m (10-ft) overall height. The stainless steel canister-wall thickness, $1.3 \mathrm{~cm}$ (1/2 in.), is determined by consideration of the lifting load at elevated temperatures, internal corrosion, external oxidation, creep, spallation, tensile stress during cooling, ruggedness factors and material of construction. 


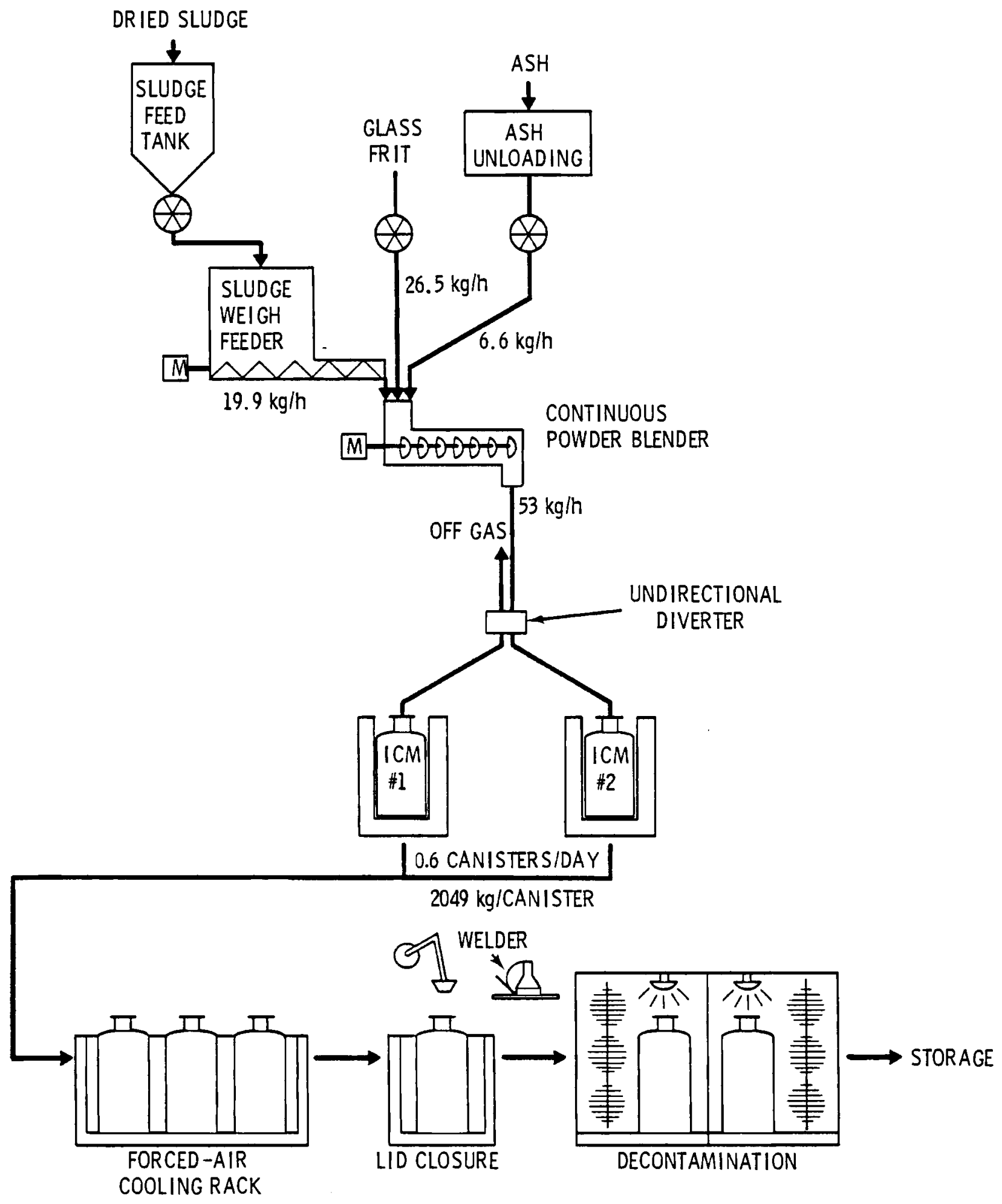

FIGURE 1. In-Can Melting Process 


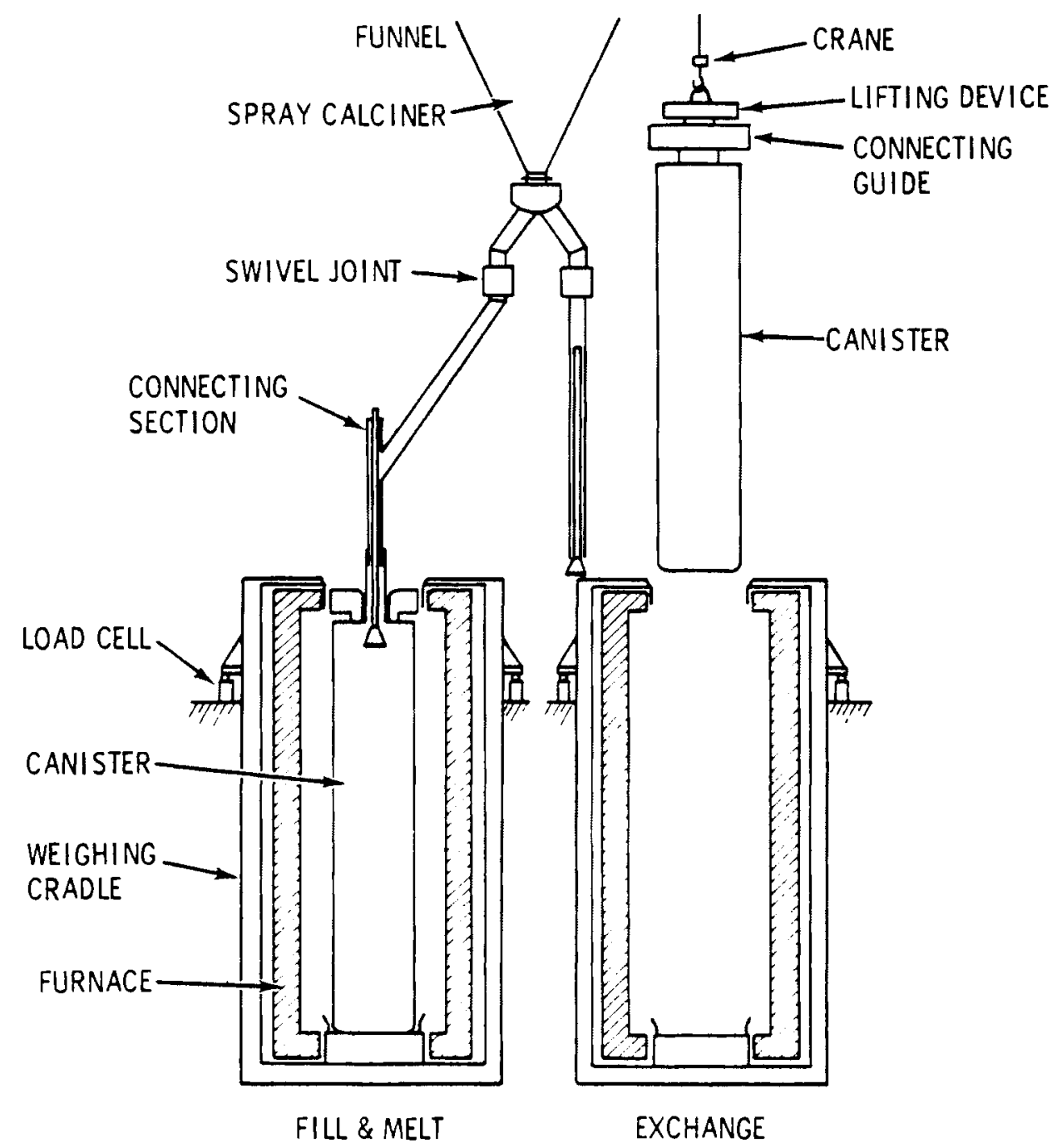

FIGURE 2. General Arrangement of ICM System

A free space of approximately $30 \mathrm{~cm}$ (11.8 in.) at the top of the canister is required to accommodate some glass pile-up and potential foaming problems. In addition, $20 \mathrm{~cm}(7.9 \mathrm{in}$.) is required for a handling device that is attached to the canister lid. This makes the effective glass height $2.55 \mathrm{~m}(8.4 \mathrm{ft})$ and the volume $683 \mathrm{~L}$. Based on a 50-wt\% waste loading and a glass/waste density of $3 \mathrm{~kg} / \mathrm{L}$, each canister can accommodate $1025 \mathrm{~kg}$ of blended TRU waste in a 2049-kg glass/waste melt.

Assuming an average design melting rate of $80 \mathrm{~kg} / \mathrm{h}$ for a $61-\mathrm{cm}-\mathrm{dia}$ canister, a 26-h fill-time for each canister (or 0.9 canister/d) can be anticipated. 


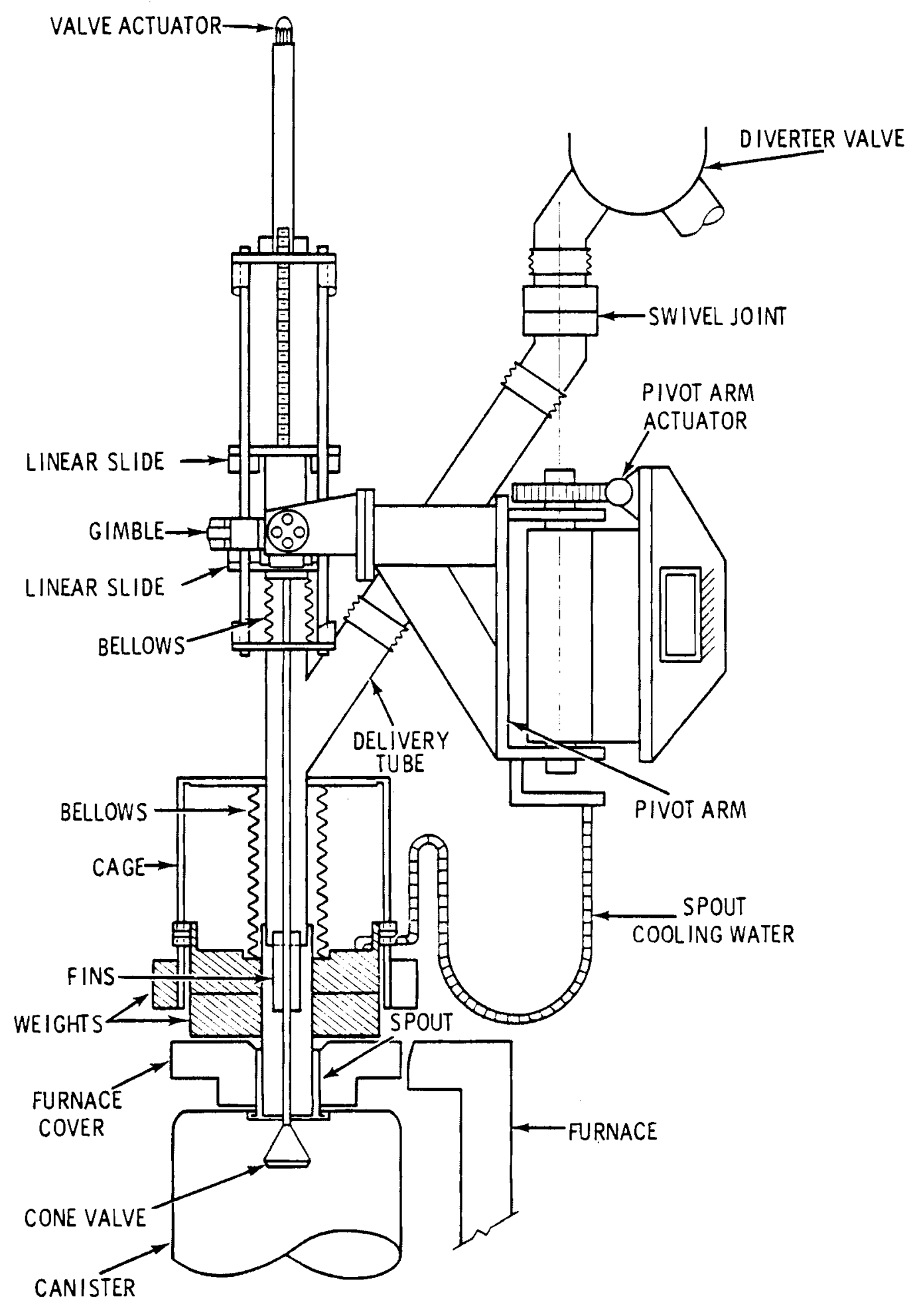

FIGURE 3. Schematic of the ICM Connecting Section 
Considering the operating-time cycle of $40.5 \mathrm{~h}$ indicated in Table 2 , and since the fill rate matches the production rate, two ICM's will be used to meet production.

When a canister is full, the waste and glass frit continue to melt completely at a temperature of $\sim 1050^{\circ} \mathrm{C}$ over a period of $3.5 \mathrm{~h}$. After complete melting, a cooldown period is initiated. Once the canister has recovered sufficient tensile strength (at $\sim 700^{\circ} \mathrm{C}$ ), the canister is removed and transferred to a forced-air cooling rack. There, it is cooled further to prevent excessive devitrification of the monolith and to enable subsequent handling. The canister is then transferred to a lid-closure station where the 1 id is remotely welded to the canister. Finally, the exterior of the canister is decontaminated and the canister is transported to storage.

TABLE 2. Canister Operating-Time Cycle

\begin{tabular}{lcc}
\multicolumn{1}{c}{ Operations } & Time, $h$ \\
\cline { 1 - 1 } Place Canister in Melter and Connect & & 2.0 \\
Heat Empty Canister & 3.5 \\
Fill & 26. \\
Top and A11 ow Bubble Release & 3.5 \\
Cool to $700^{\circ} \mathrm{C}$ & 3.5 \\
Disconnect, Remove Canister from Melter & 2.0 \\
TOTAL & 40.5
\end{tabular}

\section{JOULE-HEATED GLASS-MELTING PROCESS}

The Joule-Heated Glass-Melting (JHGM) process also produces large glass/ waste monoliths. In the JHGM process (Figure 4), dried sludge, ash and borosilicate glass frit are metered into a continuous powder blender for mixing. The blender regulates the flow of the mixture into the joule-heated glass melter where the mixture forms a cold-cap of material on top of a reservoir of molten waste glass. The operation is semi-continuous since the molten-glass level can rise in the melter while drums are being changed. Glass flow can be increased to $150 \mathrm{~kg} / \mathrm{h}$ (Buelt et a1. 1979) to meet design production demands. 


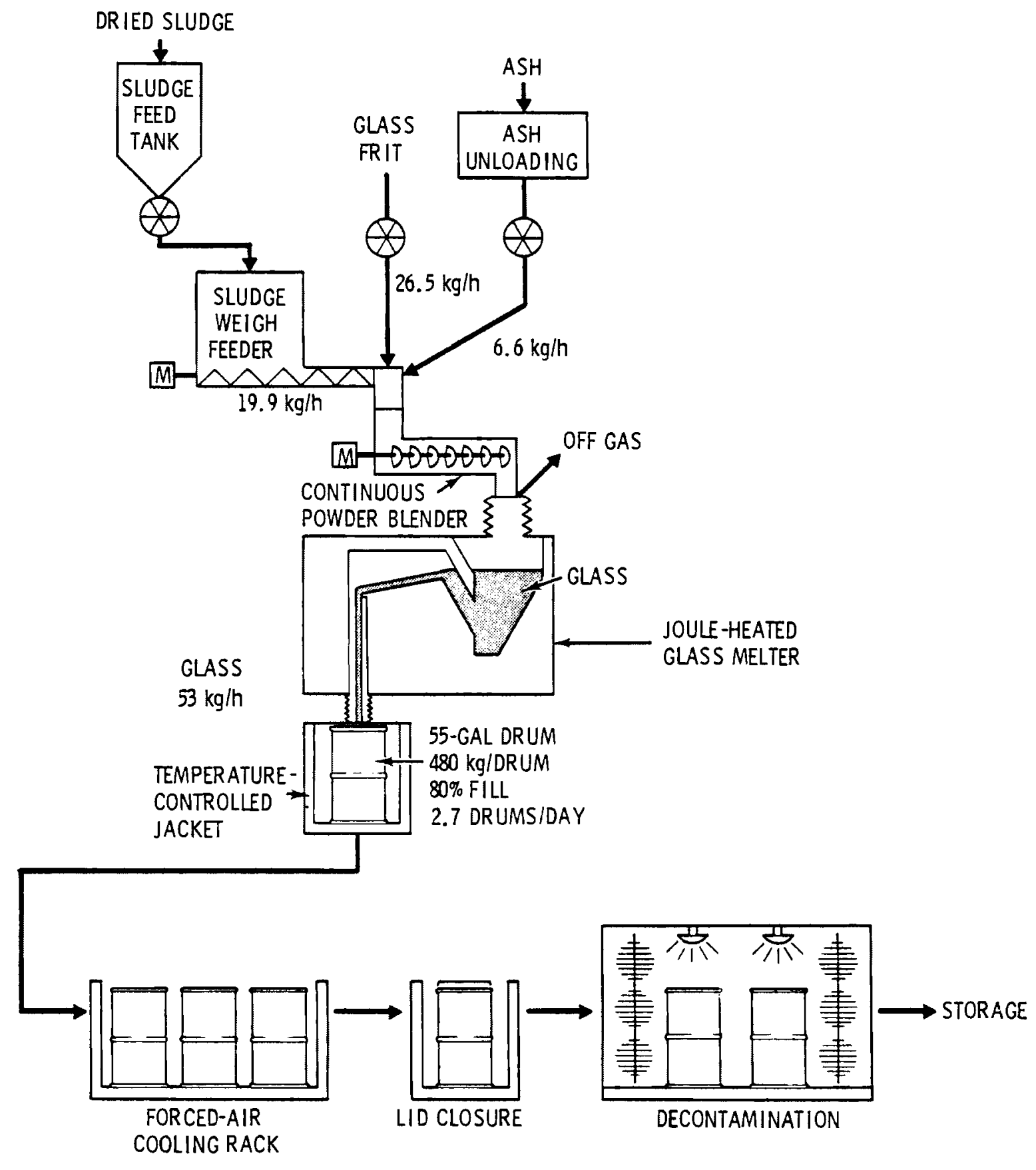

FIGURE 4. Joule-Heated Glass-Melting Process 
Melting energy is supplied to the melter by an alternating current that passes through the molten glass between immersed Incone ${ }^{\circledR} 690$ electrodes.

The molten glass at $1050^{\circ} \mathrm{C}$ is drawn up via an air-lift system from the bottom of the melter into a heated overflow trough witinin the melter as illustrated in the schematic cutaway view in Figure 5. The molten glass is then poured into 55-gal drums enclosed in a temperature-controlled jacket for initial drum heatup to prevent thermal shock and for cooldown purposes after the drum is filled. The average operating rate of the melter for this process is $53 \mathrm{~kg} / \mathrm{h}$. At this rate, or even at the design rate of $80 \mathrm{~kg} / \mathrm{h}$, no problems using a regular 55-gal mild-steel drum are envisioned, especially using the temperature-controlled jacket. Also, because the glass has already been formed in the melter, container-filling can be carried out much more rapidly than in the ICGM process. In addition, because of this rapid filling, the JHGM drums will not be exposed to temperatures as high as those of the canisters in the ICGM process.

Assuming a 50-wt\% waste loading and a borosilicate glass/waste density of $3 \mathrm{~kg} / \mathrm{L}$, a drum filled $80 \%$ will contain $480 \mathrm{~kg}$ of waste glass. At operating conditions, 2.7 drums will be filled per day or 1 drum every $9 h$.

After a drum is filled, it is transferred to a forced-air cooling rack for faster cooling to prevent devitrification of the glass and to enable subsequent handling of the drum. Then, the drum is moved to a glove-box station for emplacement of a standard ring-type lid closure. Finally, the exterior of the drum is decontaminated and the drum is transferred to storage.

The joule-heated glass melter can also be used to produce a glass ceramic or a high-temperature aluminosilicate or basaltic-type glass. The glass ceramic can be formed by controlled devitrification of the glass in the canister, which forms crystalline phases. This devitrification can be accomplished by a slow-controlled cooldown of the canister or by a rapid cooling down to $650^{\circ} \mathrm{C}$ followed by a controlled heatup to $850^{\circ} \mathrm{C}$ to recrystallize the glass. High-temperature $\left(1300^{\circ} \mathrm{C}\right)$ glasses are currently being evaluated to determine if they are significantly better than the borosilicate glasses. The

BHuntington Alloys, International Nickel Co. 


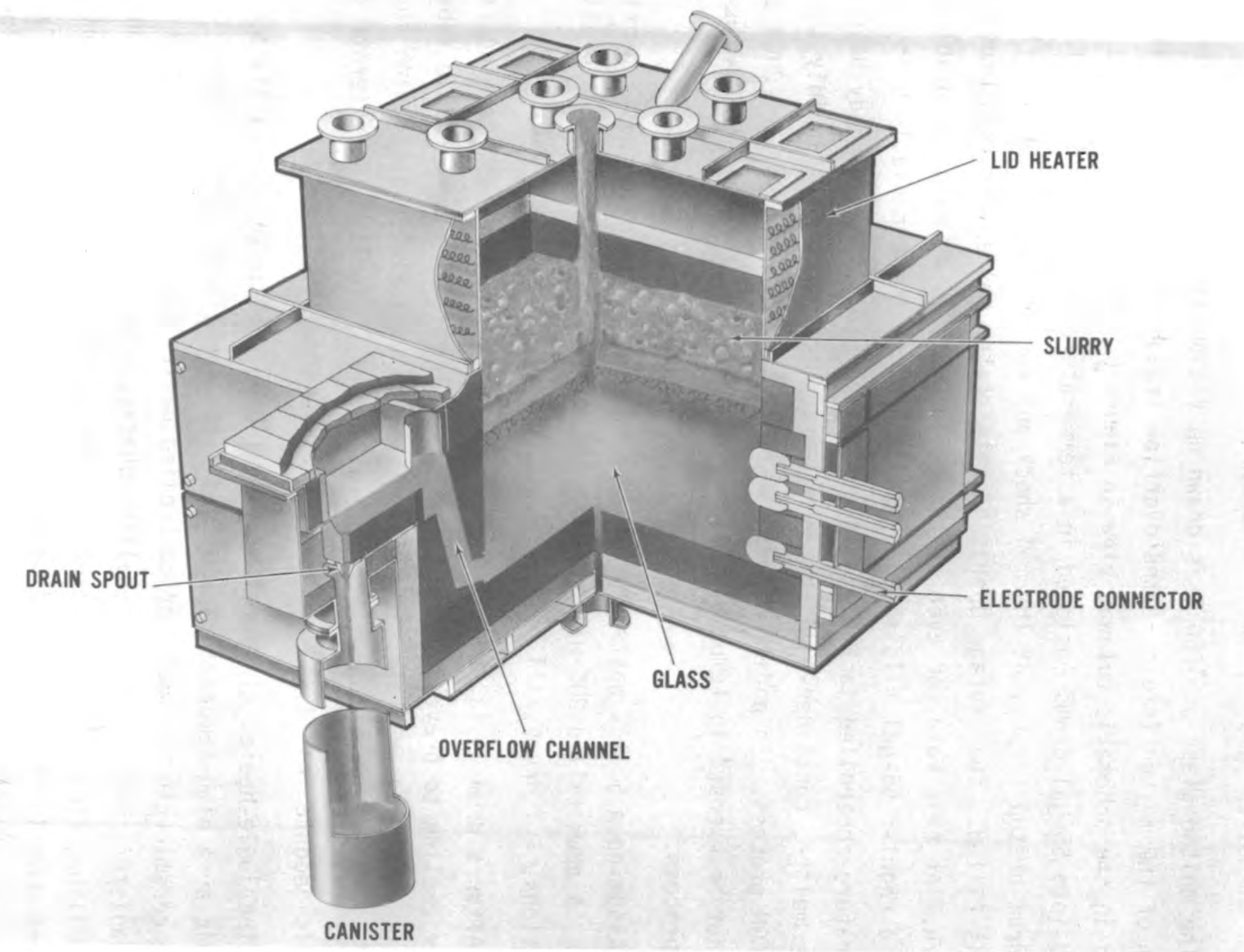

FIGURE 5. Joule-Heated Glass Melter 
higher operating temperatures for these glasses require that the melter have tin oxide electrodes rather than Inconel 690 to achieve and withstand these high melting temperatures.

\section{GLASS-MARBLE PROCESS}

The glass-marble process produces $\sim 1$-cm-dia marbles of a glass/waste mixture. As described in the JHGM process, the ash, sludge and glass frit are fed into a continuous powder blender for mixing. The blend flows from the blender directly onto the surface of the molten glass in the melter. Again, the melting energy for this melter is supplied by an alternating current that passes through the molten glass between immersed electrodes. The newly added material continuously settles and melts into the molten glass. As new frit and TRU wastes are melted, glass is drawn from the bottom of the melter, raised to an overflow trough, and continuously discharged as a thin molten stream.

The molten glass stream is poured into an enclosure housing the marble machine (Treat et al. 1980) as depicted in Figure 6. The marble machine is the first unit in the process that deviates from the JHGM process. As the glass stream leaves the melter, it pours into moving vibrating molds. As the molds move along a vibrating track, the molten glass forms semimolten spheres, which cool rapidly to form marbles. This glass-pouring and marble-forming operation is shown in Figure 7. When the molds reach the end of the vibrating track, the glass marbles fall from the molds onto a vibrating sorter.

The sloping, vibrating sorter is located in the enclosure under the exit end of the marble machine. Spherical marbles roll off one area of the sorter and are then fed into a pneumatic transfer system. Slag, glass ribbons, and broken or deformed marbles do not roll and, hence, are vibrated off the sorter and fall to the bottom of the marble-machine enclosure, where they are fed into a mill for crushing and recycling.

A glass-flow diverter assembly is another route the glass may take when being poured from the melter. This equipment allows almost instantaneous diversion of the glass flow from the marble machine in case of some process upset and is only in operation long enough for the glass stream from the melter to 


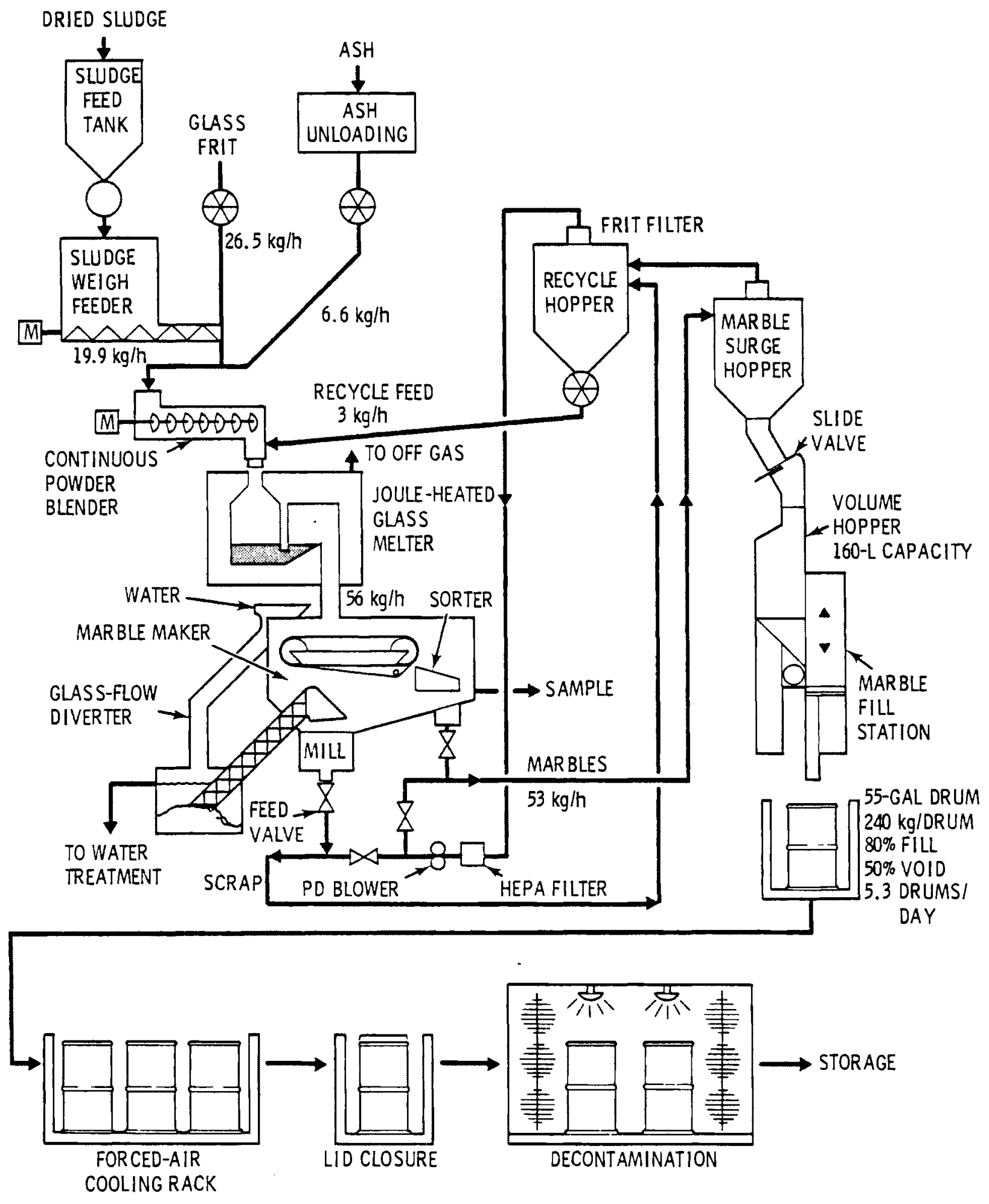

FIGURE 6. Glass Marble Process 


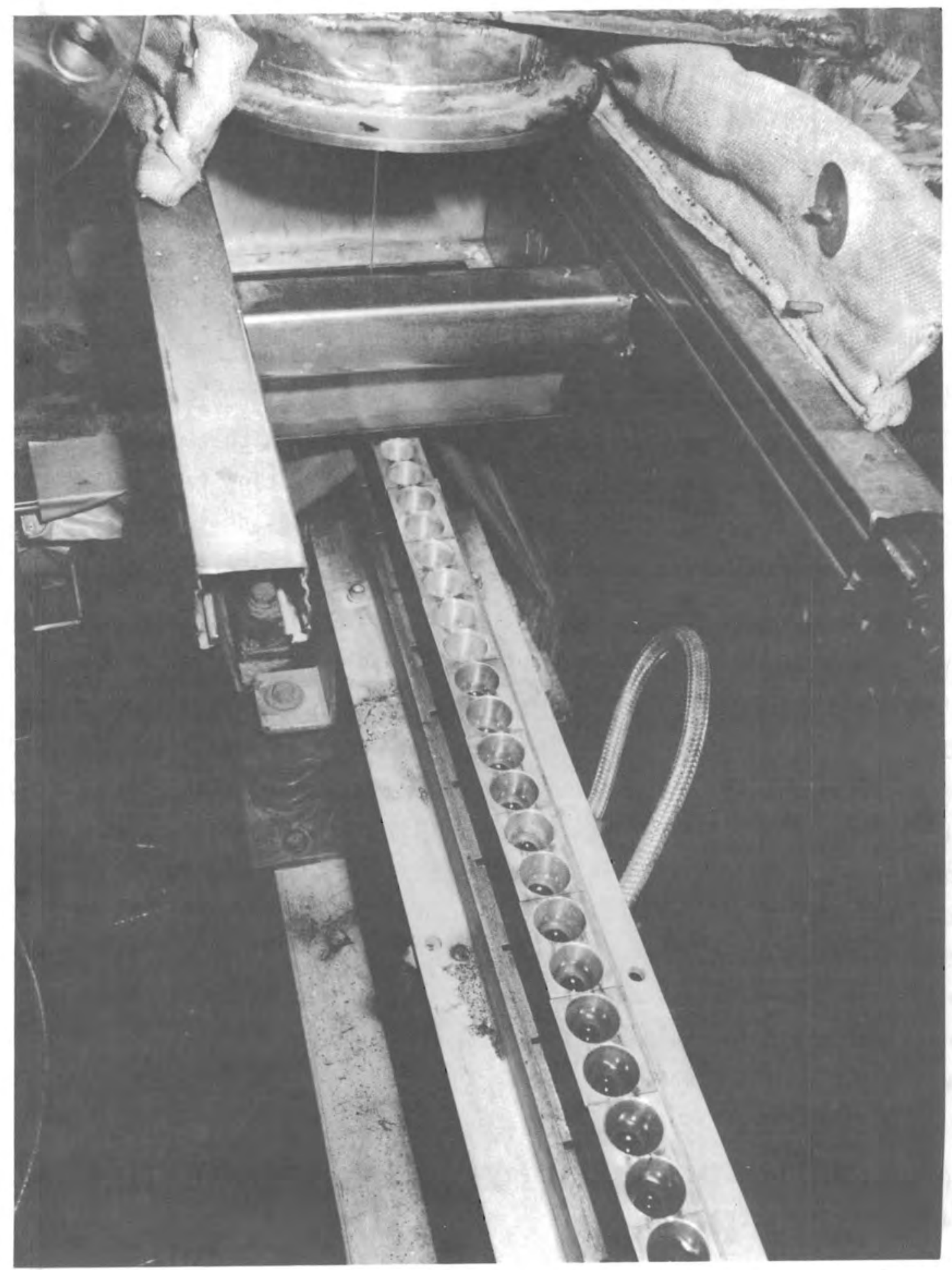

FIGURE 7. Glass Pouring and Marble Formation 
be discontinued. The flow diverter consists of a funnel and a chute leading to a storage vessel. When in use, water is continuously flowing in this diverter system, causing the glass to fracture and form glass frit again. This glass frit is augered from the storage vessel into the marble machine enclosure for feeding into the mill along with the scrap from the marble machine operation.

When enough material is accumulated, the mill is operated to reduce the glass material to particle sizes that can be conveyed in a pneumatic system and recycled into the melter. This solid-process scrap material is conveyed to a recycle hopper located at a sufficient elevation above the melter to allow gravity-controlled feeding from the hopper into the melter.

The closed, negative-pressure pneumatic system with two loops is anticipated 1) to transport acceptable marbles at an operating rate of $53 \mathrm{~kg} / \mathrm{h}$ to a marble surge hopper, and 2) to convey ground scrap glass to the recycle hopper at rates up to and equal to that of the glass production.

The surge hopper collects the marbles conveyed via the pneumatic system. Glass fines that may have been conveyed with the marbles are separated and carried out the top of the surge hopper via the pneumatic system to the scrap recycle hopper. From the surge hopper, the marbles flow to the volume hopper via gravity for a volumetric measurement. When filled, the volume hopper contains approximately $160 \mathrm{~L}$ or $80 \%$ of the fill of a 55 -gal drum. Closing the upper slide valve establishes the batch size to be fed to the drum. A fill mechanism directs and controls the flow of $240 \mathrm{~kg}$ of marbles to the drum (assuming a 50\% void). At the operating flowrate, 5.3 drums will be filled per day. The benefits anticipated from this additional processing--glass marble manufacture--include ease of sampling for quality control, negligible devitrification, and ease of product recycling.

After the drum is filled, it is transferred for cooling and lid emplacement and closure. The drum is then inspected, decontaminated if necessary, and transferred to storage.

The flow numbers associated with Figure 6 are for the nominal operating flowrates. These numbers are based on a 50-wt\% waste loading in the borosilicate glass that has a $3 \mathrm{~kg} / \mathrm{L}$ density. This allows for an average operating 
melting rate of $56 \mathrm{~kg} / \mathrm{h}$ assuming a $5 \%$ recycle rate. The $80 \%$ drum-fill of the volume hopper also considers a $50 \%$ void in the total volume.

\section{CEMENT PROCESSES}

The operating basis of the cement process differs from the other processes in that it is designed to operate on an $8-h / d, 5-d / w k, 43-w k / y r$ schedule instead of the $24-h / d, 300-d / y r$ schedule assumed for the other processes. The ash and sludge are added to this process without a preblending step because the blending operation is performed by a cement/grout mixer. The ash is added to the grout mixer at an average rate of $26.8 \mathrm{~kg} / \mathrm{h}$, while the sludge rate is $85.6 \mathrm{~kg} / \mathrm{h}(83.9 \mathrm{~kg} / \mathrm{h}$ of new sludge plus $1.7 \mathrm{~kg} / \mathrm{h}$ of process recycle). Cement additives are introduced at $208.7 \mathrm{~kg} / \mathrm{h}$ to the mixer, forming a $35-w \mathrm{t} \%$ waste blend and a 65-wt\% cement mixture. The processing water is input according to a water/solids ratio of 0.395 or $126.8 \mathrm{~kg} / \mathrm{h}$ which has experimentally been found sufficient to produce a flowable mix. Another additive to the mixer is $4.5 \mathrm{~kg} / \mathrm{h}$ ( $1 \%$ of the total mixer throughput) of off-gas filter media used for dust and moisture entrapment. These flowrates produce a nonaggregate, cast, cement waste-form with an overall waste loading of $25 \mathrm{wt} \%$. The flowsheet for this cast cement process is shown in Figure 8 .

The above materials are batched into the grout mixer to provide $160 \mathrm{~L}$ of cement mix. This cement batch is then mixed for 3 to 5 min. The wet batch of cement mix is centrifugally discharged to a feed hopper for loading into 55-gal drums. With an assumed wet-cement density of $2 \mathrm{~kg} / \mathrm{L}, 320 \mathrm{~kg}$ of cement/waste are expected for the $80 \%$ fill of each drum; thus, 11.4 drums/d are produced.

The cement mixer is flushed at least once daily. Flush solutions are pumped to the filter feed tank for processing through the rotary drum filter. Approximately $1.7 \mathrm{~kg} / \mathrm{h}$ of solids ( $1 \%$ of flushings at $169.3 \mathrm{~kg} / \mathrm{h}$ ) are incorporated into the sludge stream from these flushings.

An optional post-mixing treatment to this process is to uniaxially press the unbound or free water from the the cement. This processing concept is being developed at the Mound Facility (Lewis 1980). Using this pressing operation, small cement pellets measuring $5.1 \mathrm{~cm}(2 \mathrm{in.})$ in dia by $5.1 \mathrm{~cm}$ (2 in.) in 


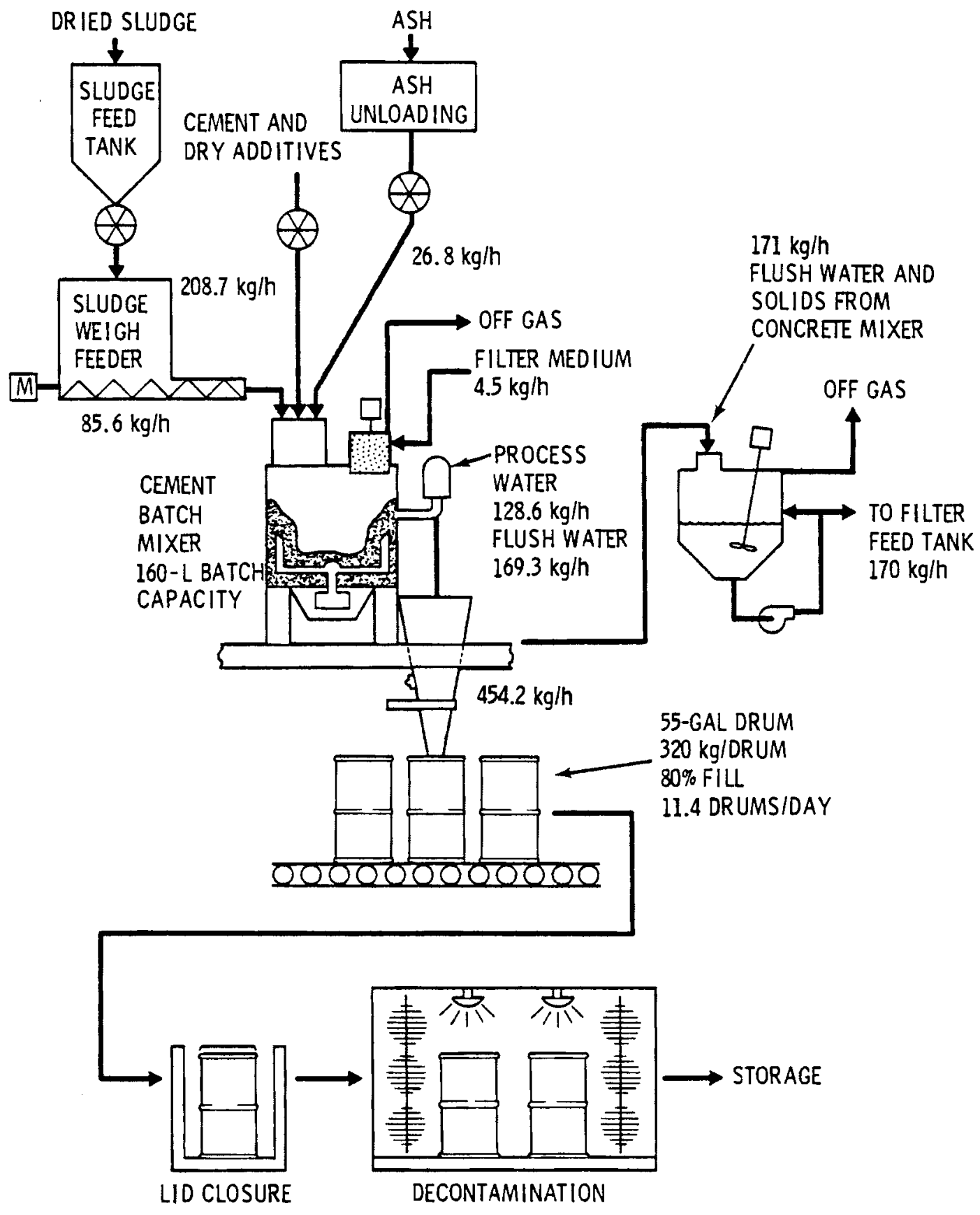

FIGURE 8. Cast Cement Process 
length would be produced. This process option has the same combined sludge/ ash feedrate of $112.4 \mathrm{~kg} / \mathrm{h}$ as the previously described cement process. This pressing option allows a $40-w t \%$ waste and $60-w t \%$ cement mixture to be fed to the mixer. Again, as in the prior cement process, a filter media for dust and moisture is slowly added to the mixer at $1 \%$ of the throughput rate, or $4.2 \mathrm{~kg} / \mathrm{h}$. Process water at the rate of $142.6 \mathrm{~kg} / \mathrm{h}$ is added to supply a water/ solids ratio of 0.5 for flowability consideration.

As shown in Figure 9, the moist cement mixture flows from the mixer to three 36.3-MT (40-ton) hydraulic presses. These presses are required to meet the design pellet-production rate of approximately 40 pellets/min. In the pressing step, pellets $5.1 \mathrm{~cm}$ (2 in.) in dia with a length-to-diameter ratio of 1.0 are manufactured. Approximately $172 \mathrm{MPa}(25,000 \mathrm{psi})$ is required to produce pellets with a density of $1.92 \mathrm{~kg} / \mathrm{L}$. The water in the mixture is used as the die lubricant. During the pressing operation, about $80 \%$ of the water $(117.4 \mathrm{~kg} / \mathrm{h})$ in the mixture is forced from the die, leaving a water/solids ratio of 0.1 in the final pressed pellet. The water is collected in an interim storage tank and recycled to the filter feed tank for incorporation back into the sludge processing.

After ejection from the die, the pellets are stored for $1 \mathrm{~d}$ for dry-curing before being loaded into a storage or shipping container. Of the $320.3 \mathrm{~kg} / \mathrm{h}$ of pellets produced, it is estimated that upon visual inspection approximately $2 \%$ of the pellets will be broken, cracked, or damaged in some manner. These $6.4 \mathrm{~kg} / \mathrm{h}$ of damaged pellets will be crushed and recycled back to the mixer for reprocessing. The $319.9 \mathrm{~kg} / \mathrm{h}$ (or 1588 pellets $/ \mathrm{h}$ ) of cured pellets are loaded into a 55-gal drum to an $80 \%$ fill. The bulk pellets are estimated to have a $50 \%$ void volume. Thus, $153.6 \mathrm{~kg}$ of pellets with an overall pellet wasteloading of $35 \mathrm{wt} \%$ are loaded into each drum. Sixteen and three-tenths drums are assumed to be loaded per day. As in the glass marbles process, the benefits of an interim processing step--pressing of pellets--include the ease of performing quality assurance and recycling, in addition to achieving potential higher waste-loading and a lower gas generation rate caused by the radiolysis of water. 


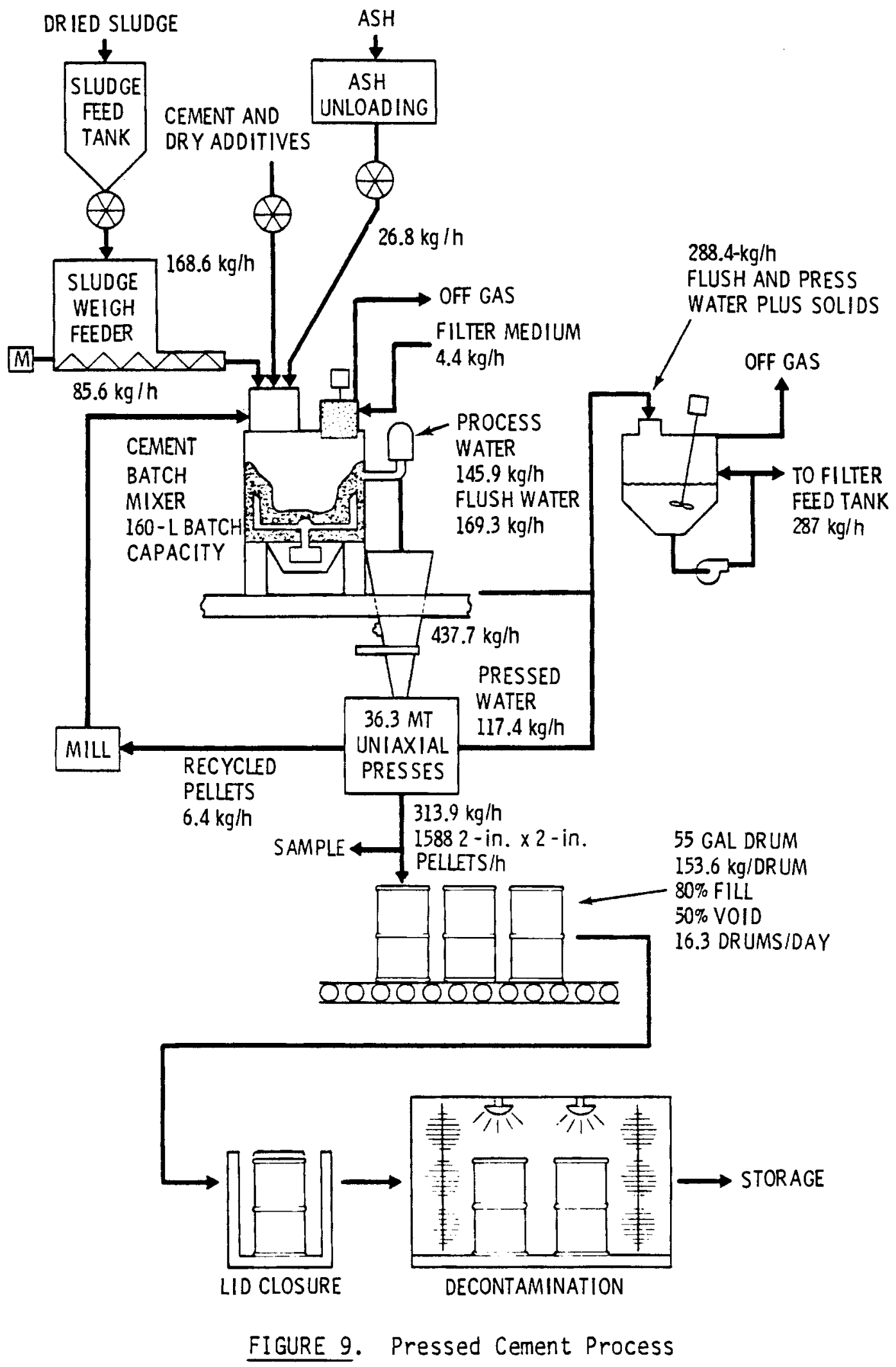


From the drum-loading station, the drums from either cement process are transferred for lid closure, inspection, decontamination as necessary, and storage.

\section{COLD-PRESSED SINTERED-CERAMIC PROCESS}

The head-end processing of the Cold-Pressed Sintered-Ceramic (CPSC) process through the powder blender is similar to that of the glass processes, except that a clay mineral, such as bentonite or another sintering additive, is introduced to the sludge/ash blend instead of glass frit. The input rates to the powder blender, as shown in Figure 10, for a 24-h/d, 300-d/yr facility are sludge, $19.9 \mathrm{~kg} / \mathrm{h}$; ash, $6.6 \mathrm{~kg} / \mathrm{h}$; and bentonite, $53 \mathrm{~kg} / \mathrm{h}$. The bentonite additive assumes a $33-w t \%$ waste loading.

From the powder blender, the material is batched into a vibratory grinding mill for size reduction to increase the reactive surface area to better promote the formation of desirable ceramic phases. The milled material is airclassified to 400 mesh or below, with the coarser material recycled back to the vibratory grinding mill for further size reduction. The appropriate size material is then pneumatically transferred to the press surge hopper for storage prior to the cold-pressing operation. The pneumatic air and any carry-over fines leaving the press surge hopper are transported to the recycle hopper for incorporation back into the vibratory grinding mill.

The milled blend is gravity-fed from the press surge hopper to a 9.1-MT (10-ton) uniaxial cold press of hydraulic design. The material is pressed into $5.1-\mathrm{cm}(2-\mathrm{in}$.$) -dia by 5.1-\mathrm{cm}(2-\mathrm{in}$.$) -long pellets at a pressure of 14 \mathrm{MPa}$ $(2,000 \mathrm{psi})$. The design flowrate requires production of $12 \mathrm{pellets} / \mathrm{min}$, which can be accomplished by one pressing unit. Once the pellets have been formed, they are passed on to a sintering furnace where they are sintered at $1000^{\circ} \mathrm{C}$ for $2 \mathrm{~h}$ under atmospheric conditions. The green density of the pellets is approximately $1.7 \mathrm{~kg} / \mathrm{L}$, while the sintered density increases to approximately $2.5 \mathrm{~kg} / \mathrm{L}$. 



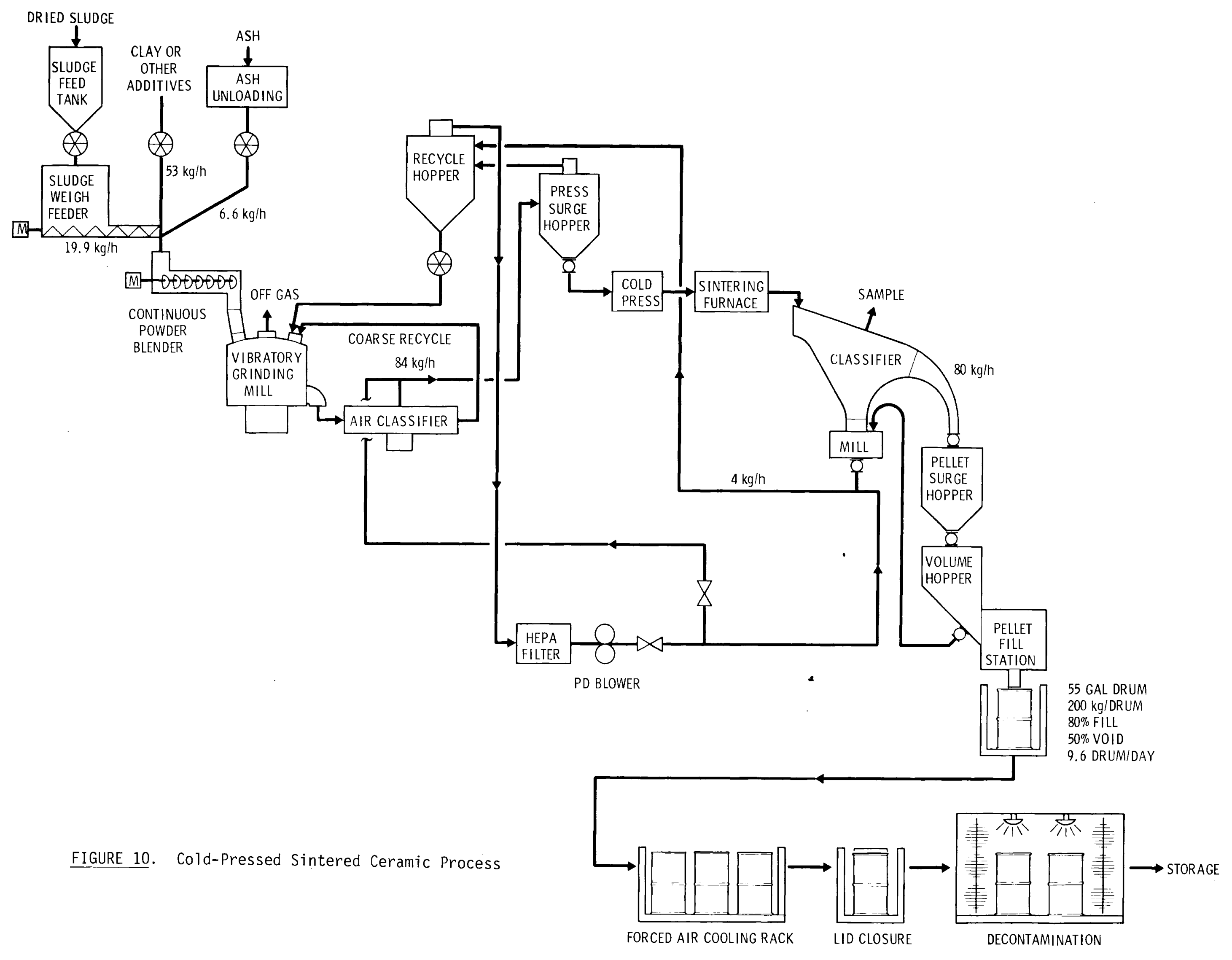



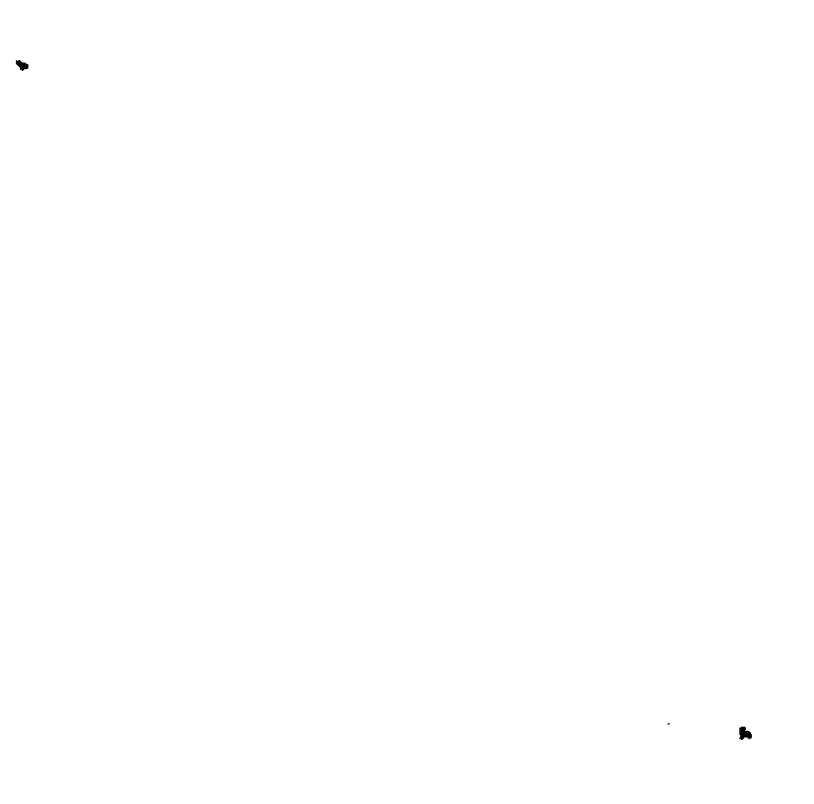
After sintering, the pellets are transferred to a screen classifier for dust, and broken pellet or chip removal. Good pellets (chipped pellets are assumed acceptable) continue on to the pellet surge hopper for eventual loadout. The dust and pellet chips are vibrated to the bottom of the classifier where they fall into a mill for crushing into particles that can be conveyed via a pneumatic system and delivered to the recycle hopper. This solidprocess scrap material is gravity-fed to the vibratory grinding mill from the recycle hopper for incorporation back into the process.

The closed, negative-pressure pneumatic system has two functions: 1) to transport finely milled material to the press surge hopper at an operating rate of $84 \mathrm{~kg} / \mathrm{h}$ and 2) to convey ground scrap pellet material to the recycle hopper at an average rate of $4 \mathrm{~kg} / \mathrm{h}$ (assumed $5 \%$ recycle) but with a design rate equal to that of sintered pellet production.

The pellet surge hopper allows pellets to flow via gravity to a volume hopper for volumetric loading to a 55-gal drum. A full-volume hopper contains approximately $160 \mathrm{~L}$ or an $80 \%$ fill of a 55-gal drum. The pellet fill station attached to the volume hopper controls and directs the pellet flow into the drum. Each drum will hold $200 \mathrm{~kg}$ of pellets assuming a $50 \%$ void volume in the drum at an $80 \%$ fill. At this loading, 9.6 drums/d will be required to meet the operating flowrate.

After the drum is filled, it is transferred for cooling, lid closure, inspection, decontamination and storage. 


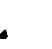




\section{CONCLUSIONS}

All the processes described are viable options for producing a stable, immobilized waste-form for the selected transuranic wastes. The benefits of the various waste-form products have previously been studied (Palmer et al. 1980). This report has identified the unit operations, equipment, process materials, and immobilized waste volumes for each system. Because of the high generation rate of TRU wastes, waste volumes need to be considered in choosing a TRU waste-form and process to minimize handling, transportation, and repository volumes and costs. A summary of daily operating volumes of containerized waste and the waste loading for each process is provided in Table 3 . This table represents the nominal container volume generated daily; the number of containers required per day; and the total overall waste loading on a weight percent basis. The waste loading column in Table 3 includes the weight of the waste, the immobilizing media, the air in the void spaces, and the container. This column provides an indication of the waste loading when the container weight is taken into account. For reference, the weight-percent waste loading in the waste form is also shown. These numbers will be helpful in choosing an economical and practical waste form and process as this study continues. This information, along with the concepts, descriptions and flowrates presented in this report, will be used to further evaluate the costs and feasibilities of producing a stable TRU waste-form.

TABLE 3. TRU Waste Volume and Loading Considerations

\begin{tabular}{|c|c|c|c|c|}
\hline \multirow[b]{2}{*}{ Process } & \multicolumn{2}{|c|}{$\begin{array}{c}\text { Volume of } \\
\text { Containerized Waste }\end{array}$} & \multicolumn{2}{|c|}{ Total Waste Loading } \\
\hline & $\mathrm{L} / \mathrm{d}$ & Containers/d(a) & Container, wt\% & Waste form, wt\% \\
\hline $\begin{array}{l}\text { In-can melting } \\
\text { Joule-heated melting } \\
\text { Glass marble } \\
\text { Cast cement } \\
\text { Pressed cement } \\
\text { Cold-pressed } \\
\quad \text { sintered ceramic }\end{array}$ & $\begin{array}{r}460 \\
530 \\
1060 \\
2280 \\
3260 \\
1920\end{array}$ & $\begin{array}{r}0.6 \\
2.7 \\
5.3 \\
11.4 \\
16.3 \\
9.6\end{array}$ & $\begin{array}{l}38.3 \\
48.0 \\
46.2 \\
23.6 \\
31.8 \\
30.4\end{array}$ & $\begin{array}{l}50 \\
50 \\
50 \\
25 \\
35 \\
33\end{array}$ \\
\hline
\end{tabular}

(a) All processes use a 55-gal drum container except the in-can melting process

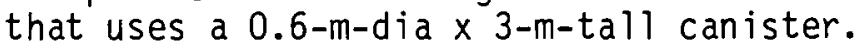




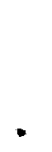

- 
Blair, H. T. 1979. In-Can Melting Process and Equipment Development from 1974 to 1978. PNL-2925, Pacific Northwest Laboratory, Richland, Washington.

Buelt, J. L., C. C. Chapman, S. M. Barnes and R. D. Dierks. 1979. "A Review of Continuous Ceramic-Lined Melters and Associated Experience at PNL." PNL-SA-7590, Pacific Northwest Laboratory, Richland, Washington.

Lewis, E. L. 1980. Pelletized Waste Form Demonstration Program: Final Design Criteria for Waste Pelletization. MLM-2697, Mound Facility, Miamisburg, ohio.

Palmer, C. R., G. B. Mellinger and J. M. Rusin. 1980. "Investigation of Vitreous and Crystaliine Ceramic Materials for Immobilization of AlphaContaminated Residues." IAEA-SM-246/40, International Symposium on the Management of Alpha-Contaminated Wastes, International Atomic Energy Agency, Vienna, Austria, June 2-6, 1980.

Treat, R. L., et al. 1980. Preliminary Evaluation of Alternative Waste Form Solidification Process, Volume I: Identification of the Processes.

PNL-3244, Pacific Northwest Laboratory, Richland, Washington. 


\section{DISTRIBUTION}

No. of

Copies

\section{OFFSITE}

A. A. Churm

DOE Chicago Patent Group

9800 South Cass Avenue

Argonne, IL 60439

2 R. Y. Lowrey

DOE Albuquerque Operations Office

P. 0. Box 5400

Albuquerque, NM 87185

A. L. Taboas

DOE Albuquerque Operations Office

P. 0. Box 5400

Albuquerque, NM 87185

S. A. Mann

DOE Chicago Operations and Region office

Argonne, IL 60439

J. Neff

Department of Energy

Columbus Program office

$505 \mathrm{King}$ Avenue

Columbus, $\mathrm{OH} 43201$

J. P. Hamric

DOE Idaho Operations office 550 2nd St.

Idaho Falls, ID 38401

J. W. Peel

DOE Idaho Operations office 550 2nd St.

Idaho Falls, ID 38401

2 J. B. Whitsett

DOE Idaho Operations office 550 2nd St.

Idaho Falls, ID 38401
No. of

Copies

C. R. Cooley

DOE Nuclear Waste Management Programs

NEW, B-107, HQ

Washington, DC 20545

G. H. Daly

DOE Nuclear Waste Management Programs

NEW, B-107, HQ

Washington, DC 20545

J. E. Dieckhoner

DOE Nuclear Waste Management Programs

NEW, B-107, HQ

Washington, DC 20545

C. H. George

DOE Nuclear Waste Management Programs

NEW, B-107, HQ

Washington, DC 20545

C. A. Heath

DOE Nuclear Waste Management Programs

NEW, B-107, HQ

Washington, DC 20545

M. L. Lawrence

DOE Nuclear Waste Management Programs

NEW, B-107, HQ

Washington, DC 20545

D. J. McGoff

DOE Nuclear Waste Management Programs

NEW, B-107, HQ

Washington, DC 20545 
No. of

Copies

S. Meyers/R. Romatowski

DOE Nuclear Waste Management

Programs

NEW, B-107, HQ

Washington, DC 20545

G. Derte1

DOE Nuclear Waste Management

Programs

NEW, B-107, HQ

Washington, DC 20545

A. F. Perge

DOE Nuclear Waste Management

Programs

NEW, B-107, HQ

Washington, DC 20545

R. W. Ramsey, Jr.

DOE Nuclear Waste Management Programs

NEW, B-107, HQ

Washington, DC 20545

D. L. Vieth

DOE Nuclear Waste Management Programs

NEW, B-107, HQ

Washington, DC 20545

R. D. Walton

DOE Nuclear Waste Management Programs

NEW, B-107, HQ

Washington, DC 20545

2 S. W. Ahrends

DOE Oak Ridge Operations Office

P. 0. Box E

Oak Ridge, TN 37830

D. Large

DOE Oak Ridge Operations Office

P. 0. Box E

Oak Ridge, TN 37830
No. of

Copies

2 S. G. Harbinson

DOE San Francisco Operations Office

1333 Broadway

Oakland, CA 94612

E. S. Goldberg

DOE Savannah River Operations Office

P. 0. Box A

Aiken, SC 29801

T. B. Hindman

DOE Savannah River Operations Office

P. 0. Box A

Aiken, SC 29801

R. P. Whitfield

DOE Savannah River Operations Office

P. 0. Box A

Aiken, SC 29801

J. H. Warren

Los Alamos Scientific Laboratory

P. 0. Box 1663

Los Alamos NM 87544

J. B. Martin

Division of Waste Management

Nuclear Regulatory Commission

Washington, DC 20555

D. M. Rohrer

Division of Waste Management Nuclear Regulatory Commission Washington, DC 20555

R. Dale Smith

Division of Waste Management

Nuclear Regulatory Commission Washington, DC 20555 
R. E. Cunningham

Office of Nuclear Safety Materials and Safeguards Nuclear Regulatory Commission Room 562, 7915 Eastern Avenue Silver Springs, MD 20910

27 DOE Technical Information Center

J. A. Buckham

All ied-General Nuclear Services

P. 0 . Box 847

Barnwe11, SC 29812

J. W. Bartlett

The Analytical Sciences Corp.

6 Jacob Way

Reading, MA 01867

J. H. Kittel

Argonne National Laboratory

Office of Waste Management Programs

9700 South Cass Avenue

Argonne, IL 60439

N. E. Carter

Battelle Memorial Institute

Office of Nuclear Waste Isolation

$505 \mathrm{King}$ Avenue

Columbus, $\mathrm{OH} 43201$

2 Beverly Rawles

Battelle Memorial Institute

Office of Nuclear Waste Isolation

505 King Avenue

Columbus, $\mathrm{OH} 43201$

R. G. Garvin

E. I. Du Pont de Nemours a Co.

Savannah River Laboratory

Aiken, SC 29801
L. W. Meyer

E. I. Du Pont de Nemours a Co.

Savannah River Laboratory

Aiken, SC 29801

G. B. Levin

EG a $G$ Idaho

P. 0. Box 1625

Idaho Falls, ID 83415

T. Smith

EG a G Idaho

P. 0. Box 1625

Idaho Falls, ID 83415

R. Williams

Electric Power Research Institute

$3412 \mathrm{Hillview} \mathrm{Avenue}$

P. 0. Box 10412

Palo Alto, CA 94304

Environmental Protection Agency

Technological Assessment

Division (AW-559)

Office of Radiation Programs

U.S. Environmental Protection Agency

Washington, DC 20460

R. A. Brown

Exxon Nuclear Idaho

P. 0. Box 2800

Idaho Fälls, ID 83401

G. L. Ritter

Exxon Nuclear Idaho

P. 0. Box 2800

Idaho Falls, ID 83401

File Copy

Exxon Nuclear Idaho

P. 0. Box 2800

Idaho Falls, ID 83401 
No. of

Copies

J. D. Tewhey

Lawrence Livermore Laboratory

P. 0. Box 808

Livermore, CA 94550

L. C. Bardium

Los Alamos Scientific Laboratory

P. 0. Box 1663

Los Alamos, NM 87545

D. Dressen

Los Alamos Scientific Laboratory

P. 0. Box 1663

Los Alamos, NM 87545

J. Doty

Monsanto Research Corporation

Mound Laboratory

P. 0. Box 32

Miamisburg, $\mathrm{OH} 45342$

K. Gilbert

Monsanto Research Corporation

Mound Laboratory

P. 0. Box 32

Miamisburg, $\mathrm{OH} 45342$

C. J. Kershner

Monsanto Research Corporation

Mound Laboratory

P. 0. Box 32

Miamisburg, $\mathrm{OH} 45342$

E. F. Lewis

Monsanto Research Corporation

Mound Laboratory

P. 0. Box 32

Miamisburg, $\mathrm{OH} 45342$

R. E. Blanco

Oak Ridge National Laboratory

P. 0. Box $Y$

Oak Ridge, TN 37830

J. 0. B Tomeke

Oak Ridge National Laboratory

P. 0. Box Y

Oak Ridge, TN 37830
No. of

Copies

A. L. Lotts

Oak Ridge National Laboratory

P. 0. Box $X$

Oak Ridge, TN 37830

J. G. Moore

Oak Ridge National Laboratory

P. 0. Box $X$

Oak Ridge, TN 37830

R. S. Lowrie

Oak Ridge National Laboratory

P. O. Box Y

Oak Ridge, TN 37830

H. Recht

Dept. 737-710

Atomics International Division

Rockwe 11 International

Box 309

Canoga Park, CA 91304

W. S. Bennett

Rockwell International

Rocky Flats Plant

P. 0. Box 464

Golden, CO 80401

L. R. Crisler

Rockwe 17 International

Rocky Flats Plant

P. 0. Box 464

Golden, CO 80401

Lawrence J. Smith

Rockwell International

Rocky Flats Plant

P. 0. Box 464

Golden, CO 80401

E. Vejvoda

Rockwell International

Rocky Flats Plant

P. 0. Box 464

Golden, CO 80401 
No. of

Copies

J. W. Mckiernan

Sandia National Laboratory

P. 0. Box 5800

Albuquerque, NM 87185

M. Molecke

Sandia National Laboratory

P. 0. Box 5800

A lbuquerque, NM 87185

W. Weart

Sandia Laboratories

Albuquerque, NM 87185

E. Albenesius

Savannah River Laboratory

Aiken, SC 29801

D. L. McIntosh

Savannah River Laboratory

Aiken, SC 29801

P. Macedo

Vitreous State Laboratory

Catholic University of America

Washington, DC 20064

R. G. Post

College of Engineering

University of Arizona

Tucson, AZ 85721

F. K. Pittman

3508 Sagecrest Terrace

Ft. Worth, TX 76109

\section{ONSITE}

7 DOE Richland Operations Office

E. A. Bracken

P. A. Craig

R. E. Gerton

H. E. Ransom

J. J. Schreiber

M. W. Shupe

M. J. Zamorski
No. of

Copies

12 Rockwell Hanford Operations

H. Babad

R. A. Deju

R. J. Gimera

D. R. Gustavson

E. J. Kosiancic

C. M. Manry

S. J. Phillips

J. H. Roecker

D. D. Wodrich (3)

File Copy

UNC United Nuclear Industries

T. E. Dabrowski

Westinghouse Hanford Company

A. G. Blasewitz

57 Pacific Northwest Laboratory

R. P. Allen

W. J. Bjork lund

W. F. Bonner

G. H. Bryan

L. A. Chick

T. D. Chikalla

A. D. Chockie

C. M. Devary

L. J. Ethridge

L. K. Fetrow

D. W. Fraley

W. J. Gray

C. R. Hann

M. S. Hanson

A. J. Haverfield

J. H. Jarrett

D. E. Knowiton

W. L. Kuhn

L. T. Lakey

D. E. Larson

R. 0. Lokken

G. B. Long (2)

N. W. McCoy

S. A. McCullough

R. P. May 
No. of

Copies

Pacific Northwest Laboratory (contd)

J. L. McElroy

G. B. Mellinger

R. E. Nightingale

C. R. Palmer

L. D. Perrigo

A. M. Platt
No. of

Copies

D. L. Prezbindowski (2)

W. A. Ross

J. M. Rus in

J. L. Ryan

C. L. Timmerman (10)

R. L. Treat

R. P. Turcotte

J. H. Westsik, Jr.

Technical Information (5)

Publishing Coordination Vi (2) 